\title{
PENCEGAHAN PENYALAHGUNAAN BAHAYA NARKOBA PADA SISWA KELAS VIII-E MELALUI LAYANAN BIMBINGAN KELOMPOK DI SMP NEGERI 1 LUBUK PAKAM
}

\author{
Rumidah \\ Guru Bimbingan dan Konseling SMP Negeri 1 Lubuk Pakam \\ Surel : s.rumidah@yahoo.co.id
}

\begin{abstract}
ABSTRAK
Penelitian ini bertujuan untuk meningkatkan pencegahan bahaya narkoba siswa melalui layanan bimbingan kelompok bagi siswa kelas VIII-E SMP Negeri 1 Lubuk Pakam Semester Genap Tahun Ajaran 2014/2015. Berdasarkan hasil observasi, siswa yang belum mengalami peningkatan pada pertemuan pertama siklus I dan mengalami peningkatan pada pertemuan kedua siklus I sebesar $40 \%$ masuk pada kategori sedang. Kemudian peningkatan terjadi lagi pada pertemuan ketiga siklus II sebesar $60 \%$ masuk kategori cukup baik dan meningkat kembali pada pertemuan keempat pada siklus II sebesar $80 \%$ masuk kategori baik. Sedangkan target yang ingin dicapai $75 \%$, sehingga hipotesis yang berbunyi "Peranan Layanan Bimbingan Kelompok Dalam Mencegah Bahaya Penyalahgunaan Narkoba Pada Siswa Kelas VIII-E SMP Negeri 1 Lubuk Pakam Tahun Ajaran 2014/2015" dapat diterima.
\end{abstract}

Kata Kunci : Pencegahan, Narkoba, Layanan Bimbingan Kelompok

\section{PENDAHULUAN}

Kasus penyalahgunaan narkoba meningkat dengan cepat di Indonesia, meskipun pemerintah dan masyarakat telah melakukan berbagai upaya. Penyalahgunaan narkoba memang sulit diberantas. Yang dapat dilakukan adalah mencegah dan mengendalikan agar masalahnya tidak meluas, sehingga merugikan masa depan bangsa, karena merosotnya kualitas sumber daya manusia terutama generasi mudanya.

Penyalahgunaan narkoba berkaitan erat dengan peredaran gelap sebagai bagian dari dunia kejahatan internasional. Mafia perdagangan gelap memasok narkoba, agar orang memiliki ketergantungan, sehingga jumlah suplai meningkat. Terjalin hubungan antara pengedar/bandar dan korban. Korban sulit melepaskan diri dari mereka, bahkan tak jarang mereka terlibat peredaran gelap, karena meningkatnya kebutuhan narkoba.

Penderita ketergantungan obat-obatan terlarang atau kini umumnya berusia 15-24 tahun. Kebanyakan mereka masih aktif di sekolah menengah pertama, sekolah menengah atas, atau perguruan tinggi. Bahkan, ada pula yang masih duduk di bangku di sekolah dasar.

Penyalahgunaan narkoba biasanya diawali dengan pemakaian pertama pada usia SD atau SMP, karena tawaran, bujukan, dan tekanan seseorang atau kawan sebaya. Didorong pula oleh rasa ingin tahu dan rasa ingin mencoba, mereka mnerima bujukan tersebut. Selanjutnya akan dengan mudahnya 
untuk dipengaruhi menggunakan lagi, yang pada akhirnya menyandu obat-obatan terlarang dan ketergantungan pada obat-obatan terlarang.

Narkoba (Narkotika dan Obat-obatan yang mengandung zat adiktif/berbahaya dan terlarang) belakangan ini amat populer di kalangan remaja dan generasi muda bangsa Indonesia, sebab penyalahgunaan narkoba ini telah merebak ke semua lingkungan, bukan hanya di kalangan anak-anak nakal dan preman tetapi telah memasuki lingkungan kampus dan lingkungan terhormat lainnya. Narkoba saat ini banyak kita jumpai di kalangan remaja dan generasi muda dalam bentuk kapsul, tablet dan tepung seperti ekstasy, pil koplo dan shabu-shabu, bahkan dalam bentuk yang amat sederhana seperti daun ganja yang dijual dalam amplop-amplop.

Saat ini para orang tua, mulai dari ulama, guru/dosen, pejabat, penegak hukum dan bahkan semua kalangan telah resah terhadap narkoba ini, sebab generasi muda masa depan bangsa telah banyak terlibat di dalamnya. Akibat leluasannya penjualan narkoba ini, secara umum mengakibatkan timbulnya gangguan mental organik dan pergaulan bebas yang pada gilirannya merusak masa depan bangsa.

Permasalahan narkoba saat ini telah membahayakan remaja. Pemberitaan di media massa tentang penangkapan produser narkoba yang telah memproduksi ribuan narkoba membuat kita prihatin. Indonesia tidak hanya menjadi daerah pemasaran gelap narkoba tetapi juga sebagai daerah produser narkoba. Hingga kini penyebaran narkoba sudah hampir tak bisa dicegah. Bandar narkoba aktif mencari mangsa yang tidak hanya orang dewasa melainkan telah menyebar di daerah sekolah, sehingga banyak pelajar yang terjerumus narkoba.

Jumlah

kasus

penyalahgunaan dan peredaran

gelap narkoba yang dilaporkan terus meningkat, pada tahun 1999 berjumlah 1.833 kasus, tahun 2000 berjumlah 3.478 kasus dan pada tahun 2001 berjumlah 3.617 kasus (sumber data Badan Narkotika Nasional). Tentu saja hal ini bisa membuat para orang tua, serta pemerintah khawatir akan penyebaran narkoba yang begitu merajalela. Upaya pemberantasan narkoba pun sudah sering dilakukan, namun masih sedikit kemungkinan untuk menghindarkan narkoba dari kalangan remaja maupun dewasa, bahkan anak-anak usia SD dan SMP pun banyak yang terjerumus narkoba.

Berdasarkan latar belakang masalah yang telah diuraikan dapat diidentifikasi permasalahan yang relevan terhadap pembelajaran BK di SMP Negeri 1 Lubuk Pakam diantaranya: (1) Bahaya penyalahgunaan narkoba pada siswa, (2) Upaya mencegah bahaya narkoba melalui layanan bimbingan kelompok, (3) Peran serta orangtua, guru dan pemerintah dalam mencegah bahaya narkoba pada siswa. Berdasarkan identifikasi masalah, rumusan masalah adalah (1) "Apakah Layanan Bimbingan Kelompok Dapat Mencegah Bahaya Penyalahgunaan Narkoba Pada Siswa Kelas VIII-E SMP Negeri 1 Lubuk Pakam Tahun Ajaran 2014/2015". Adapun tujuan penelitian yang akan dicapai adalah 
(1) Untuk mencegah bahaya penyalahgunaan narkoba pada siswa melalui pemberian layanan bimbingan kelompok siswa kelas VIII-E SMP Negeri 1 Lubuk Pakam Tahun Ajaran 2014/2015".

\section{METODE PENELITIAN}

Penelitian ini akan dilaksanakan SMP Negeri 1 Lubuk Pakam yang beralamat di Jalan Kartini Lubuk Pakam. Penelitian ini dilaksanakan pada semester genap Tahun Pelajaran 2014/2015 selama 5 (bulan) bulan mulai dari bulan Maret sampai dengan Juli 2015. Pengambilan data dilaksanakan selama 4 (empat) KBM yang dibagi dalam 2 (dua) Siklus. Subjek penelitian ini adalah siswa kelas VIII-E SMP Negeri 1 Lubuk Pakam yang berjumlah 35 siswa dan didapat 10 oirang siswa yang akan di berikan layanan bimbingan kelompok. Penelitian ini berbentuk Penelitian Tindakan Kelas (PTK). Penelitian tindakan kelas adalah penelitian yang dilakukan oleh guru di kelas atau di sekolah dengan penekanan pada penyempurnaan atau peningkatan proses pembelajaran. Dalam satu siklus terdiri atas empat langkah, yaitu perencanaan (planning), tindakan (acting), observasi (observing) dan refleksi (reflecting).

\section{HASIL PENELITIAN DAN PEMBAHASAN \\ Deskripsi Awal}

Kondisi awal siswa VIII-E yang menyangkut pencegahan bahaya narkoba pada melalui bimbingan konseling.

\section{Hasil Penelitian Siklus I}

Pre-test diberikan untuk menjaring responden yang memiliki pengendalian diri yang paling rendah. Berdasarkan data dari hasil pre-test diambil 10 responden yang memiliki skor terendah. 10 responden tersebut dimasukkan dalam pemberian layanan bimbingan kelompok. Dari 10 responden didapat skor tertinggi 45 dan skor terendah 31 , dengan rata-rata $(\mathrm{M})=$ 37,4 . Hasil perhitungan data pretest yang diperoleh dapat dilihat pada tabel sebagai berikut:

Tabel Hasil Pre-test Siklus I

\begin{tabular}{|l|l|l|}
\hline No & Statistik & $\begin{array}{l}\text { Kelas } \\
\text { Eksperimen }\end{array}$ \\
\hline 1 & N & 10 \\
\hline 2 & Rata-rata & 37,4 \\
\hline 3 & Maksimum & 45 \\
\hline 4 & Minimum & 31 \\
\hline
\end{tabular}

Berdasarkan data yang diperoleh dari hasil penelitian dengan jumlah responden 10 orang terdapat skor tertinggi 61 dan skor terendah 49 , dengan rata-rata $(\mathrm{M})=$ 53,9. Hasil perhitungan data post-test yang diperoleh dapat dilihat pada tabel berikut:

Tabel Hasil Post-test Siklus I

\begin{tabular}{|l|l|l|}
\hline No & Statistik & $\begin{array}{l}\text { Kelas } \\
\text { Eksperimen }\end{array}$ \\
\hline 1 & N & 10 \\
\hline 2 & Rata-rata & 53,9 \\
\hline 3 & Maksimum & 61 \\
\hline 4 & Minimum & 49 \\
\hline
\end{tabular}

Dalam tahap refleksi Siklus I dan perencanaan Siklus II peneliti melakukan pertemuan diskusi kembali untuk mengidentifikasi kelemahan Siklus I dan aktivitas belajar yang perlu diperbaiki serta merancang tindakan perbaikan pada 
perencanaan Siklus II. Pada siklus I terdapat kelemahan siswa belum mampu jujur atau bertindak seperti keadaan yang sebenarnya.

Beberapa penyebab yang teridentifikasi adalah :

1. Dalam kegiatan bimbingan kelompok, siswa masih merasa canggung dengan kegiatan layanan konseling yang dilakukan.

2. Pada refleksi siswa belum mengetahui tujuan dan manfaat yang akan di peroleh dari layanan bimbingan kelompok yang dilakukan.

3. Beberapa siswa belum memiliki kesadaran tentang pentingnya konseling bagi mereka.

\section{Hasil Penelitian Siklus II}

Peneliti

kembali menyebarkan angket untuk mengetahui seberapa besar pemahaman siswa mengenai bahaya narkoba. Dari 10 responden didapat skor tertinggi 72 dan skor terendah 37 , dengan rata-rata $(M)=59,5$. Hasil perhitungan data pretest yang diperoleh dapat dilihat pada tabel sebagai berikut:

Tabel Hasil Pre-test Siklus II

\begin{tabular}{|l|l|l|}
\hline No & Statistik & $\begin{array}{l}\text { Kelas } \\
\text { Eksperimen }\end{array}$ \\
\hline 1 & N & 10 \\
\hline 1 & Rata-rata & 59,5 \\
\hline 3 & Maksimum & 72 \\
\hline 4 & Minimum & 37 \\
\hline
\end{tabular}

Berdasarkan data yang diperoleh dari hasil penelitian dengan jumlah responden 10 orang terdapat skor tertinggi 75 dan skor terendah 44 , dengan rata-rata $(\mathrm{M})=$ 66,5 . Hasil perhitungan data post- test yang diperoleh dapat dilihat pada tabel berikut:

Tabel Hasil Post-test Siklus II

\begin{tabular}{|l|l|l|}
\hline No & Statistik & $\begin{array}{l}\text { Kelas } \\
\text { Eksperimen }\end{array}$ \\
\hline 1 & N & 10 \\
\hline 2 & Rata-rata & 66,5 \\
\hline 3 & Maksimum & 75 \\
\hline 4 & Minimum & 44 \\
\hline
\end{tabular}

Berdasarkan tabel 3 dan tabel 4. rata-rata data Pre-test lebih rendah dari pada rata-rata data Post-test. Jadi, ada pencegahan bahaya penyalahgunaan narkoba pada diri siswa saat mereka di hadap pada posisi yang merugikan mereka.

\section{Pembahasan}

Jika dilihat dari hasil perhitungan rata-rata telah diketahui bahwa pada test Siklus I pencegahan penyalahgunaan bahaya narkoba pada siswa berada pada rata-rata 38,4. Setelah diberikan layanan bimbingan kelompok Siklus II diperoleh rata-rata 101,6.Tampak bahwa rata-rata pencegahan penyalahgunaan narkoba siswa lebih tinggi setelah diberikan layanan bimbingan kelompok.

Dengan demikian dinyatakan layanan bimbingan kelompok dapat meningkatkan pencegahan penyalahgunaan narkoba pada siswa kelas VIII-E di SMP Negeri 1 Lubuk Pakam T.P 2014/2015.

\section{KESIMPULAN}

Dari hasil penelitian dapat disimpulkan bahwa layanan bimbingan kelompok dapat meningkatkan pencegahan penyalahgunaan narkoba pada siswa 
kelas VIII-E SMP Negeri 1 Lubuk Pakam T.P 2014/2015.

\section{DAFTAR RUJUKAN}

Agustian, A. G. 2007. Rahasia Sukses Membangun Kecerdasan Emosi dan Spiritual ESQ:

Arikunto, Suharsini. 2009. Manajemen Penelitian. Jakarta: Rineka Cipta.

Corey, Gerald. 2009. Teori dan Praktek Konseling \& Psikoterapi. Bandung: Rafika Aditama.

Damayanti, nidya. 2012. Buku Pintar Panduan Bimbingan konseling. Yogyakarta: Araska.

Emotional Spiritual Quotient Berdasarkan 6 Rukun Iman dan 5 Rukun Islam. Jakarta: ARGA Publishing.

Fakultas Ilmu Pendidikan Universitas Negeri Medan. 2013. Pedoman Penulisan Skripsi. Medan: FIP UNIMED.

Prayitno \& Erman Amti. 1994. Dasar-Dasar Bimbingan dan Konseling. Jakarta: P2LPTK Depdikbud.

Prayitno \& Erman Amti. 2004. Dasar-Dasar Bimbingan dan Konseling. Jakarta: Rineka Cipta.

Nggermanto, A. 2002. Quantum Quotient (Kecerdasan Quantum): Cara Cepat Melejitkan IQ, EQ dan $S Q$ Secara Harmonis. Bandung: Penerbit Nuansa.

Rumidah. (2015). Peranan Layanan Bimbingan Kelompok Dalam Mencegah Bahaya Penyalahgunaan Narkoba Pada Siswa Kelas VIII-E
SMP Negeri 1 Lubuk Pakam

Tahun Ajaran 2014/2015.(PTK). Karangan Sendiri. 
